\title{
Mathematical Training as a Means of Forming the General Scientific Competency of Economists
}

\author{
Roza Valentinovna Baturina ${ }^{1, *}$, Galiya Bulatovna Khasanova ${ }^{2}$ \\ ${ }^{1}$ Department of Natural Sciences and Information Technologies, Kazan National Research Technical University Named after A. N. \\ Tupolev - KAI, Kazan, Russia \\ ${ }^{2}$ Department of Social Work, Pedagogics and Psychology, Kazan National Research Technological University, Kazan, Russia
}

Received August 20, 2020; Revised October 4, 2020; Accepted October 24, 2020

\section{Cite This Paper in the following Citation Styles}

(a): [1] Roza Valentinovna Baturina, Galiya Bulatovna Khasanova, "Mathematical Training as a Means of Forming the General Scientific Competency of Economists, "Universal Journal of Educational Research, Vol. 8, No. 11B, pp. 6116 6123, 2020. DOI: 10.13189/ujer.2020.082247.

(b): Roza Valentinovna Baturina, Galiya Bulatovna Khasanova (2020). Mathematical Training as a Means of Forming the General Scientific Competency of Economists. Universal Journal of Educational Research, 8(11B), 6116 - 6123. DOI: 10.13189/ujer.2020.082247.

Copyright $\bigcirc 2020$ by authors, all rights reserved. Authors agree that this article remains permanently open access under the terms of the Creative Commons Attribution License 4.0 International License

\begin{abstract}
In the context of the deepening socio-economic crisis, the training of qualified economists who must solve important issues concerning timely anticipation of crisis events, predictive assessments of their depth and scale, and the development of effective measures against adverse processes and their consequences, deserves particular attention. In this regard, the importance of education and science increases significantly, which should provide specialists with modern methods of economic management, analysis of economic processes, and adequate and timely assessment of threats to economic development. The analysis of professional tasks solved by economists has shown that they should not only know the theoretical foundations and laws of the market economy functioning, but also be able to identify problems of an economic nature when analyzing specific situations, as well as suggest ways to solve them and assess the expected results, systematize and generalize information, possess methods for analyzing the production and economic activities of an enterprise and evaluating its market positions, and more. Therefore, the list of professional competencies of an economist should include general scientific competency - the ability and preparedness to use knowledge about quantitative relations and spatial forms of the real world, the possession of a system of categories and methods necessary to solve typical tasks in various areas of professional economic activity. Mathematical disciplines play a key role in the formation of general scientific competency in future economists. Specially organized
\end{abstract}

mathematical training allows forming a set of meta-professional knowledge, skills, and personal qualities that make it possible to ensure the greatest effect in achieving the set professional economic tasks, students' mastery of general scientific concepts, and the acquisition of research experience, which constitute the content of the economist's general scientific competency.

Keywords Economic Education, General Scientific Competency, Mathematical Training of Economists

\section{Introduction}

The key figure of the market economy is an economist, whose professional success depends on his desire and ability to take risks, readiness to use the opportunities provided by the market, and focus on searching for new ways to extend the scope of activities. Therefore, to train an economist, it is necessary to determine the essence, content, and features of his professional activity.

Economists use the most abstract information. This leads to the two most general requirements for this type of specialist: an interest in working with semiotic systems, and the ability to perceive, operate, and analyze information presented in a semiotic, abstract form. Besides, the more complex the professional tasks are (i.e. the more heterogeneous information must be taken into account in 
analytical work), the more important is the ability to see behind the dynamics of numbers the relationships of real processes that they reflect [1].

The national model of training specialists in various sectors of the national economy provides for the use of experience in the formation of competence ${ }^{1}$ acquired in the European education system. As evidenced by scientific research of this experience, competence involves the ability of a person to perceive and respond to individual and social needs, a set of relationships, values, knowledge, and skills.

The analysis of the professional activity of economists has shown that the list of professional competencies of an economist should include general scientific competency.

The general scientific competency of the economist is the ability and readiness to scientifically analyze problems and processes in the economic domain, the ability to use in practice basic knowledge and methods of mathematics and natural sciences; to set goals and formulate tasks related to the implementation of professional functions, and to use the methods of the studied disciplines to solve them; to conduct comprehensive economic research, including searching for necessary information, experimenting, analyzing, and interpreting data using basic and social knowledge, as well as contemporary methods to achieve the required results; to conduct bibliographic and information-retrieval work with the subsequent use of data in solving professional tasks and preparing scientific articles, reports, conclusions, etc. [1].

The structure of the economist's general scientific competency includes the following components.

The motivational-value component assumes the orientation of the specialist to achieve success in economic activity, readiness, as well as a professional and personal interest in the manifestation of this competency, the presence of value orientations and motives for using general scientific knowledge, abilities, skills, and personal and business qualities as the basis of general scientific competency in their professional activities. The formation dynamics of this component is associated with changes in the nature of motivation, awareness and effectiveness of motives (from external motivation to internal, from motives just understood to really applicable ones; striving to use general scientific competency in various types of professional activities and the need for their creative use).

The cognitive-operational component of this competency includes a resource fund of effective general scientific knowledge and skills (research, project, predictive, analytical, etc.) of the economist, which ensure the greatest productivity of his activities, the ability to selectively use and creatively manifest them when solving

1 Both terms - competency and competence are used in similar ways to describe the ability to do something successfully or effectively. At that, competency is described as an important skill that is needed to do a job, whereas competence is used to describe the ability to do something well. professional tasks. The dynamics of economist formation is manifested through the complexity and structuring of knowledge (from individual representations to system-structured knowledge, acting as an indicative basis for activity); in complicating the use of general scientific skills in a specific activity (when preparing term papers, making presentations at scientific conferences, and writing articles), as well as in changing the source of motivating forces - from initiating activities on the part of the teacher to manifesting personal initiative and conscious self-sufficiency.

The reflexive-evaluative component involves the ability to consciously control the results of own professional activities and the level of own professional development, as well as personal achievements; a tendency to self-analysis, the ability to anticipate, proactive, critical, and innovative reflection and forecast the results of own activities. Criteria-indicative signs of its formation are professional self-assessment (assessment of one's actions based on personally significant motives and attitudes, consisting in comparison, analysis, and correction of relations between goals, means, and consequences of actions; ability to correct own attitude), as well as professional self-control.

General scientific competency is formed mainly based on knowledge as tools that include a person who strives for knowledge and possesses strategies for cognitive activity, as opposed to knowledge as descriptions which is a set of specific scientific information about the world around. Knowledge as tools has an interdisciplinary character and serves the main tool for creating a holistic view of the world [2].

In the course of training future economists, a key role in the formation of general scientific competency is played by mathematical disciplines of the profile. In the context of specially organized mathematical training, a set of meta-professional knowledge, skills, and personal qualities of the individual is formed that allows for the greatest effect in achieving the set job tasks. While studying mathematics, students master thinking techniques and methods, such as induction and deduction, analysis and synthesis, generalization and concretization, classification and systematization, the ability to formulate, justify, and prove judgments. The means of mathematics contribute to developing strong-willed personality qualities, perseverance and purposefulness, cognitive activity, and independence, which allow exploring using mathematical methods a wide range of new economic problems, apply modern information technologies, use theoretical achievements in practice, as well as get possessed general scientific concepts and skills. In the course of studying mathematics, students gain experience in doing research, planning, forecasting, building analytical models, and processing experimental results [3]. All this leads to an increase in students' interest in both mathematics and professional disciplines. 
Process cognition and management are conducted through modeling. Therefore, the authors propose to implement the process of forming general scientific competency in future economists using a proposed model.

The scientific methodology of the present research is based on systematic, activity-based, personality-oriented, and competence-based approaches.

The modeling method was used to explain and reproduce the studied object in the following logical sequence: specialist activity model - specialist personality model specialist training model - training content model.

\section{Methods}

\subsection{Model Specification}

When constructing the model of the scientific competency formation in future economists in the course of mathematical training, the authors proceeded from the generally accepted pedagogical and philosophical science ideas about the model as a system that includes objectives, content, methods, and means, as well as the results of the educational process [4-6].

The purpose of the developed model (target unit) is to form in students of economic specialties the general scientific competency in terms of mathematical training. Specifying a goal allows defining the following tasks:

- ensuring students' motivational readiness to form general scientific competency, forming in students' basic professional values and ideals, the desire to use general scientific competency in various types of professional activities, and the need for its creative use (motivational-value component);

- forming effective scientific and theoretical knowledge and general scientific skills that ensure the highest productivity of economic activity, the ability to selectively use and creatively display knowledge and skills when executing job tasks (cognitive-operational component);

- forming reflexive and evaluative skills of understanding one's level of general scientific competency (reflexive-evaluative component).

The scientifically grounded selection of the training content (the content-related block of the model) is one of the main conditions for the effective formation of general scientific competency in future economists. Because the formation of general scientific competency occurs within the framework of mathematical disciplines, according to the research logic, the authors use different types of tasks (activity-based approach). From a large variety of types, categories, and classifications of tasks, the classification offered by V.I. Zagvyazinsky is more related to the problem of the present study [7]. The author classifies tasks based on the type of activity in the course of its solution and identifies four types: reproductive, algorithmic, transformative, and creative-search tasks. Zagvyazinsky's classification allows taking into account the age, educational, and individual capabilities of students when forming their general scientific competency.

At the first stage, associated with the acquisition of basic knowledge in the field of mathematics, as the authors' experience shows, it is advisable to use reproductive tasks that require performing all the elementary steps, i.e. performing example-based tasks, as well as training tasks.

At the productive stage, which is aimed at forming individual components and operations necessary to develop general scientific competency, an algorithmic task is used to strengthen the studied material. This task should provide for the use of the studied material in a modified form which should reflect other aspects of its possible applications. In the course of solving such tasks, students develop the ability to select a generalized solution algorithm (if possible), as well as to analyze what data are missing in the task, to determine possible solutions to tasks with incomplete data, and make a solution plan.

The creative stage is associated with the resolution of nonstandard situations that are close to the real economic activity of the specialist. The development of the student's personality and the formation of his activity are based on the integration of the achievements gained at the previous stages: theoretical scientific knowledge, personal qualities, and motivation for the use of general scientific competency in professional activities. At this stage, the formation of general scientific competency occurs through solving tasks of a situational nature. Besides, both reproductive and creative-search tasks are used to consolidate the studied topic.

The content-related component allows focusing the educational process on the formation of general scientific competency in students of economic specialties in the course of teaching mathematical disciplines. It involves teaching a cycle of general mathematical disciplines, taking into account the professional orientation of training in the content of academic courses and includes modeling of professional situations, analysis of the decision-making effectiveness, modeling and assessing professional results, as well as design of information systems [8]. The process of training students at the university is a special step in becoming a professional. Therefore, when building the learning process in a higher education institution, professional orientation should be the main principle, allowing resolving the contradictions between the theoretical nature of the studied disciplines and the need for practical application of knowledge in professional practice.

The procedural essence (the procedural block of the model) of the formation of general scientific competency is reflected and implemented through certain methods, means, and forms of teaching and learning.

It is planned to develop this type of competency in future economists using the following forms: lectures and 
practical classes, as well as educational and research work of students.

The theoretical material, which is presented in the form of a lecture, serves the basis for the subsequent formation of necessary skills and personal qualities in practical classes. The lecture encourages the student to independently search for new knowledge, develops the mental independence, draws into scientific thought, and scientific search. In the course of educational and research work, students perform term papers and theses, participate in the project developments.

Practical classes allow simulating the real working conditions of a future specialist, contributing to his individualization, differentiation of training, creative level of development of the material studied, acquisition of certain professional experience, and spark interest in the current economic situation.

Independent work of students in a variety of individual and collective activities is carried out under the guidance of a teacher, however, without his direct participation, and is conducted during a specially designated classroom or extracurricular time. This is a special form of training based on the execution of given tasks, whose solution requires intense mental activity.

Forming general scientific competency in future economists should be carried out in a purposefully modeled professional environment throughout the entire period of study at the university and be a dynamic process. This process is a sequence of motivational, theoretical, and executive stages, of which each is accompanied by an appropriate impact on the motivational and need-based sphere of the future specialist's personality.

The main goal of the motivational stage is to form a value attitude to scientific knowledge. At the theoretical stage, students acquire general scientific knowledge. This is achieved by introducing specially designed courses on certain topics in the traditional mathematical disciplines of the university educational process. The development and consolidation of general scientific skills and abilities when preparing course projects and diploma projects, as well as reflection, is carried out at the executive stage. The general scientific competency formed by students is further developed in educational and research work.

The division of the overall process of formation of scientific competency into successive stages is conditional, since the formation of the necessary skills of the future economist is inevitably accompanied by a qualitative transformation of the system of knowledge, and contributes to the formation of ideas about the nature of scientific competency, while the achievement of the required level of learning needs their application through practical professional activities. Each stage of this process is characterized by a certain basic form of organization of students' activities: academic-type educational activities, quasi-professional, or educational-professional activity. Their sequential transformation constitutes the main content of the procedural block of the model developed by the authors.

The performance-evaluative block of the proposed model reflects the state that should be obtained in the learning process. The authors have identified three levels of well-formedness of general scientific competency, namely, intuitive-reproductive, consciously-reproductive, and creative.

The intuitive-reproductive level is characteristic to students whose knowledge of the possibilities of applying mathematical concepts and theories when solving professional problems is sketchy and not systematized, not connected with real practice. These students reproduce knowledge at the level of memorization, cannot get information about the possibilities of applying mathematical theories to solving economic problems without the assistance of a teacher. For these students, it is characteristic to focus on getting the final result when solving reproductive tasks, without striving to evaluate them in terms of optimality and applicability. They do not realize the need to form a system of mathematical concepts as the fundamental basis of economic education.

The consciously-reproductive level characterizes students who are partially aware of the importance of mathematical knowledge in solving professional tasks. They manifest a growing interest in the connection of mathematics with real practice and general professional disciplines. They translate verbal information into a semiotic form independently and without mistakes, identify the algorithm for solving simple problems and use it almost without mistakes, but are not able to identify the algorithm for more complex problems. They are unable to identify whether the task has more than one solution method, and switch from the selected method to the optimal one through leading questions. They require information that would increase not only their mathematical literacy but also their professional competency. This level of well-formedness of general scientific competency is characterized by a stable performing attitude of students in the learning process. They successfully solve algorithmic and transformative tasks.

The creative level corresponds to the productive level of mathematical knowledge in solving provisionally-professional tasks. Students are free to use all possible symbols when translating complex information into the semiotic form and vice versa and can solve problems of any level. They can objectively evaluate all the proposed solutions, independently find a mistake in their reasoning and the reasoning of course mates, successfully apply mathematical knowledge to solving professional tasks, and realize their importance for self-actualization in future professional activities, come to understand that knowledge is unitary and that the world must be studied from a single standpoint.

The formation of general scientific competency in 
students is developed by stages and provides for the promotion of future economists from one level to another.

Monitoring is carried out at each stage of this process. To monitor the level of well-formedness of a certain competency, the following diagnostic methods were used: solving tasks of various levels of complexity, questionnaires, testing, self-testing, and observation. Familiarization with the results of diagnostics, comparing them with self-assessment, correlating the results with the evaluation criteria of various components of general scientific competency allows the student to define the real level of well-formedness of his general scientific competency, which is another incentive to increase his qualification level.

All blocks of the general scientific competency formation model are interconnected and represent certain integrity. Thus, the goal of forming the general scientific competency of a future economist determines its content; while the goal and content require certain methods, means, and forms of stimulating and organizing the process of forming general scientific competency which necessarily should be monitored. Each block of the model individually plays an important role, but only all the components together provide a certain result.

Thus, the model to form general scientific competency, developed by the authors, represents an open, integral, and dynamically developing system.

\subsection{Methods}

To assess the effectiveness of the developed theoretical model of general scientific competency formation in future economists in the course of mathematical training, an experimental study was conducted, which involved 117 people. The experimental group consisted of students who studied based on the proposed system (60 people), and 57 people made up the control group.

To study the results of experimental work, pedagogical diagnostics were used, namely, survey, testing, self-assessment method, description, generalization, computer processing, and systematization of empirical data.

The following indicators were used as criteria to assess the effectiveness of the system: well-formedness of the motivational-value component of general scientific competency, the degree of compliance of students' knowledge, and action methods with the learning goals (cognitive-operational component), and well-formedness of reflexive-evaluative skills (reflexive-evaluative component).

One can evaluate the effectiveness of the general scientific competency formation system for future economists by determining the level of its well-formedness. For this purpose, a special method to diagnose the level of the designated competency was developed, which can be used by the students to evaluate their achievements themselves, assessing their indicators for each of the three components.

At the ascertaining stage of the experiment, the responses of first-year students of the faculty of economics and university teachers concerning general scientific competency (a total of 117 students and 46 university teachers were interviewed) were analyzed. The results of the study have shown that students and teachers have their idea about general scientific competency and methods of implementing the educational process.

\section{Results}

Comparative analysis of the well-formedness of a motivational-value component of scientific competency in students of control and experimental groups before the experiment showed that most students were at the intuitive-reproductive and consciously-reproductive levels: $93 \%$ - in the control group; and $91.6 \%$ - in the experimental group (Table 1).

Table 1. Distribution of students by levels of well-formedness of the motivational-value component of general scientific competency

\begin{tabular}{|c|c|c|c|c|}
\hline \multirow{2}{*}{ Level } & \multicolumn{2}{|c|}{ Control group } & \multicolumn{2}{c|}{$\begin{array}{c}\text { Experimental } \\
\text { group }\end{array}$} \\
\cline { 2 - 5 } & Number & $\%$ & Number & $\%$ \\
\hline Intuitive-reproductive & 25 & 43.9 & 26 & 43.3 \\
\hline Consciously-reproductive & 28 & 49.1 & 29 & 48.3 \\
\hline Creative & 4 & 7.0 & 5 & 8.4 \\
\hline
\end{tabular}

Besides, at the ascertaining stage of experimental work, students were offered tasks of various levels of complexity. Analysis of the results of review works showed that the students of both groups solved reproductive tasks most successfully, while experienced difficulties in solving tasks of a creative and search nature (Table 2).

Table 2. Distribution of students by levels of well-formedness of the cognitive-operational component of general scientific competency

\begin{tabular}{|c|c|c|c|c|}
\hline \multirow{2}{*}{ Level } & \multicolumn{2}{|c|}{ Control group } & \multicolumn{2}{c|}{$\begin{array}{c}\text { Experimental } \\
\text { group }\end{array}$} \\
\cline { 2 - 5 } & Number & $\%$ & Number & $\%$ \\
\hline Intuitive-reproductive & 29 & 50.9 & 26 & 43.3 \\
\hline Consciously-reproductive & 18 & 31.6 & 22 & 36.7 \\
\hline Creative & 10 & 17.5 & 12 & 20 \\
\hline
\end{tabular}

Also, at this stage of experimental work, the authors studied the level of well-formedness of reflexive skills in students of the control and experimental groups. Table 3 shows that reflexive skills were poorly formed in almost all students.

Thus, the results of the ascertaining experiment showed that if the formation of general scientific competency is not set as a target at training future economists, then it is almost not formed automatically. 
Table 3. Distribution of students by levels of well-formedness of the reflexive-evaluative component of general scientific competency

\begin{tabular}{|c|c|c|c|c|}
\hline \multirow{2}{*}{ Level } & \multicolumn{2}{|c|}{ Control group } & \multicolumn{2}{c|}{$\begin{array}{c}\text { Experimental } \\
\text { group }\end{array}$} \\
\cline { 2 - 5 } & Number & $\%$ & Number & $\%$ \\
\hline Intuitive-reproductive & 26 & 45.6 & 24 & 40 \\
\hline Consciously-reproductive & 27 & 47.4 & 32 & 53.3 \\
\hline Creative & 4 & 7.0 & 4 & 6.7 \\
\hline
\end{tabular}

Therefore, for the effective formation of the studied competency, a well-designed system based on the developed model is required.

Then the educational experiment was carried out, which was the main part of the integrated experiment. Its essence was to implement the developed model of the formation of general scientific competency in the educational process of training future economists.

At this stage, the formation of general scientific competency of future economists was achieved through:

- changing the structure and content of the mathematical training of the future economist, which included elective education along with the compulsory courses;

- developing a set of mathematical and professional tasks and assignments with different levels of complexity;

- forming continuously general scientific competency in students;

- $\quad$ using an integrated system for monitoring progress and quality of learning, as well as surveying, which allowed determining the level of well-formedness of general scientific competency in students.

These pedagogical conditions were identified by the authors in the course of theoretical studies.

Forming the motivational-value component of the general scientific competency of future economists was consistent with forming motives and values that encouraged individuals to study mathematics.

Forming the cognitive-operational component involved the development of general scientific knowledge and skills in the course of studying mathematics, assimilation of leading ideas and concepts, the use of mathematical tools and methods in educational practice, and future professional activities.
Forming the reflexive-evaluative component of general scientific competency assumed mastering three types of reflection by the student: unconscious, conscious, and situation management reflection that should lead to a significant change in terms of personal development.

Thus, to determine the effectiveness of the model and the identified pedagogical conditions to form general scientific competency of future economists, the answers to questions from questionnaires specially developed by the authors were analyzed, as well as the success of solving problems of various levels of complexity, and the performance of coursework. The results of the educational experiment are presented in Tables 4, 5, and 6 .

Table 4. Distribution of students by levels of well-formedness of the motivational-value component of general scientific competency

\begin{tabular}{|c|c|c|c|c|}
\hline \multirow{2}{*}{ Level } & \multicolumn{2}{|c|}{ Control group } & \multicolumn{2}{c|}{$\begin{array}{c}\text { Experimental } \\
\text { group }\end{array}$} \\
\cline { 2 - 5 } & Number & $\%$ & Number & $\%$ \\
\hline Intuitive-reproductive & 17 & 29.8 & 7 & 11.6 \\
\hline Consciously-reproductive & 32 & 56.2 & 35 & 58.4 \\
\hline Creative & 8 & 14.0 & 18 & 30.0 \\
\hline
\end{tabular}

Table 5. Distribution of students by levels of well-formedness of the cognitive-operational component of general scientific competency

\begin{tabular}{|c|c|c|c|c|}
\hline \multirow{2}{*}{ Level } & \multicolumn{2}{|c|}{ Control group } & \multicolumn{2}{c|}{$\begin{array}{c}\text { Experimental } \\
\text { group }\end{array}$} \\
\cline { 2 - 5 } & Number & $\%$ & Number & $\%$ \\
\hline Intuitive-reproductive & 12 & 21.0 & 4 & 6,6 \\
\hline Consciously-reproductive & 14 & 24.6 & 12 & 20.0 \\
\hline Creative & 31 & 54.4 & 44 & 73.4 \\
\hline
\end{tabular}

Table 6. Distribution of students by levels of well-formedness of the reflexive-evaluative component of general scientific competency

\begin{tabular}{|c|c|c|c|c|}
\hline \multirow{2}{*}{ Level } & \multicolumn{2}{|c|}{ Control group } & \multicolumn{2}{c|}{$\begin{array}{c}\text { Experimental } \\
\text { group }\end{array}$} \\
\cline { 2 - 5 } & Number & $\%$ & Number & $\%$ \\
\hline Intuitive-reproductive & 5 & 9.0 & 1 & 1.7 \\
\hline Consciously-reproductive & 44 & 77.0 & 47 & 78.3 \\
\hline Creative & 8 & 14.0 & 12 & 20.0 \\
\hline
\end{tabular}

Table 7 clearly shows that the number of students who have formed all the components of general scientific competency at the highest level (creative) is much higher in the experimental group as compared to the control group.

Table 7. Distribution of students by levels of well-formedness of general scientific competency components

\begin{tabular}{|c|c|c|c|c|c|c|}
\hline \multirow{2}{*}{ Level } & \multicolumn{2}{|c|}{$\begin{array}{c}\text { Motivational-value } \\
\text { component }\end{array}$} & \multicolumn{2}{|c|}{$\begin{array}{c}\text { Cognitive-operational } \\
\text { component }\end{array}$} & \multicolumn{2}{|c|}{$\begin{array}{c}\text { Reflexive-evaluative } \\
\text { component }\end{array}$} \\
\hline & $\begin{array}{l}\text { Control } \\
\text { group }\end{array}$ & $\begin{array}{l}\text { Exp. } \\
\text { group }\end{array}$ & $\begin{array}{l}\text { Control } \\
\text { group }\end{array}$ & $\begin{array}{l}\text { Exp. } \\
\text { group }\end{array}$ & $\begin{array}{l}\text { Control } \\
\text { group }\end{array}$ & $\begin{array}{l}\text { Exp. } \\
\text { group }\end{array}$ \\
\hline & $\%$ & $\%$ & $\%$ & $\%$ & $\%$ & $\%$ \\
\hline Intuitive-reproductive & 29.8 & 11.6 & 21.0 & 6.6 & 9.0 & 1.7 \\
\hline Consciously-reproductive & 56.2 & 58.4 & 24.6 & 20.0 & 77.0 & 78.3 \\
\hline Creative & 14.0 & 30.0 & 54.4 & 73.4 & 14.0 & 20.0 \\
\hline
\end{tabular}


Thus, the results obtained in experimental work, and their versatile qualitative and quantitative analysis allowed confirming the effectiveness of the developed model and the pedagogical conditions to form general scientific competency in future economists in the course of mathematical training.

\section{Discussion}

In the literature, much attention is paid to the competencies that a future specialist in the field of economics should master.

Thus, G.V. Seraya identifies the following components of professional competency of an economist: standard competencies that create the basis to form professional skills, abilities, qualities, professional requirements to achieve the results of professional work (knowledge of the ethical standards of the profession, features, content, and requirements of professional activity, and value attitude to it); special competencies related to the professional activity of an economist (cognitive-informational, professional-technological, economic, social-communicative, and professional-managerial competencies), as well as situational professional competencies, whose content depends on the specialization of the economist (cognitive, practical, and system-based competencies) [9]. Filchenkova I.F. incorporates financial-economic, research, information-analytical, organizational- managerial competencies in the structure of professional competency of an economist that allow him to effectively carry out the main types of professional activities [10]. Khoruzhiy K.S. believes that an economist should have cognitive, activity-based, and practical, as well as communicative competencies [11].

However, the analysis of the content of the professional activity of economic specialists [12] shows that general scientific competency, whose formation is carried out in the course of mathematical training of students, should be particularly highlighted.

Foreign and domestic researchers note the need for future economists to study mathematical disciplines, and consider them an important component in the system of their fundamental training [6, 13-17]. However, according to them, studying mathematics should be primarily focused on developing in students mathematical thinking $[6,16,18]$, scientific awareness [17], various skills (cognitive, activity, research, and communicative) [14], mathematical culture [13], the ability to intellectual and creative activity $[15,19]$, etc.

According to the authors of the present research, mathematical subjects have greater potential and make it possible to form general scientific competency of future economists in the aggregate of its components (meta-professional knowledge, skills, and personal qualities), which will allow ensuring the greatest effect in achieving the set professional goals.

\section{Conclusions}

The research results allow concluding as follows:

1. The key role in the formation of the general scientific competency of future economists is played by the natural science and, especially, mathematical disciplines. In the course of mathematical training, students gain experience in research, planning, forecasting, building analytical models, processing the results of experiments. This leads to an increase in students' interest in both mathematics and general professional and special disciplines and, therefore, contributes to an increase in the quality of professional economic education.

2. A successful solution to the problem of the formation of the general scientific competency of economists can be considered a theoretical model tested in the process of their professional training, built on the basis of systemic, personality-oriented, activity-based and competence-based approaches, as well as the principles of professional orientation, personal activity, creativity, contextuality and reflexivity, and structurally consisting of target, content-related, procedural and performance-evaluative blocks. Each block of the model individually plays a large role, but only all components in the aggregate provide a certain result.

3. For the successful functioning of the model, specially created pedagogical conditions are required, as well as the readiness of teachers of mathematics and special disciplines to form and develop general scientific competency in students.

In the course of the research, new issues and problems have emerged that need to be addressed. It is necessary to continue research on the development of methods aimed at forming general scientific competency of economists in other disciplines when training in natural sciences.

\section{REFERENCES}

[1] R.V. Baturina, Aristova. Formirovanie obshchenauchnoj kompetencii bakalavrov $\mathrm{V}$ usloviyah matematicheskoj podgotovki [Forming general scientific competency of bachelors in the context of mathematical training], Kazan Science, Vol.10, 119-121, 2016.

[2] O.N. Golubeva, A.D. Sukhanov. Problema celostnosti v sovremennom obrazovanii [The problem of integrity in contemporary education], New Millennium Foundation, Moscow, 1996.

[3] R.V. Baturina. On some problems of the succession of the discipline of mathematics in the school-university system, 
European Social Science Journal, Vol.10, 441-444, 2018.

[4] Yu.K. Babansky. Problemy povysheniya effektivnosti pedagogicheskogo issledovaniya [Problems of improving the effectiveness of pedagogical research], Pedagogy, Moscow, 1982.

[5] V.N. Pishchulin, Formirovanie professional'noj kompetentnosti specialista ekonomicheskogo profilya $\mathrm{V}$ sisteme universitetskogo obrazovaniya [Formation of professional competence of a specialist of an economic profile in the system of university education]. Ph.D. thesis in pedagogical sciences, Moscow, 2006.

[6] E.I. Semushina. Matematicheskaya podgotovka budushchih ekonomistov i specialistov gosudarstvennogo i municipal'nogo upravleniya kak sostavlyayushchaya ih kachestvennogo professional'nogo obrazovaniya [Mathematical training of future economists and specialists of state and municipal management as a component of their quality professional education], Scientific Bulletin of the Ural Academy of Public Administration, Vol.2, No.3, 91-94, 2008.

[7] V.I. Zagvyazinsky. Metodologiya i metodika didakticheskogo issledovaniya [Methodology and techniques of didactic research], Pedagogika, Moscow, 1982.

[8] E.Yu. Aristova, R.V. Baturina. Methodological aspects of teaching probability theory and mathematical statistics to university students. Modern Journal of Language Teaching Methods, Vol.7, No.5, 40-44, 2017.

[9] G.V. Seraya. K voprosu o formirovanii professional'no vazhnyh kompetencij budushchih ekonomistov na zanyatiyah estestvenno-matematicheskogo cikla [On the issue of forming professionally important competencies of future economists in the classroom of the natural and mathematical cycle], New Technologies in Education, Vol.3, 76-79, 2008.

[10] I.F. Filchenkova. Formirovanie professional'noj kompetentnosti budushchih ekonomistov v vuze [Formation of professional competence of future economists in higher education]. Ph.D. thesis in pedagogical sciences. N. Novgorod, 2009.
[11] K.S. Khoruzhiy. Professional'naya kompetentnost' budushchih ekonomistov: sushchnost' i soderzhanie [Professional competence of future economists: Essence and content]. Contemporary Problems of Science and Education, 6, 2014.

[12] L.S. Grebnev. Filosofiya ekonomiki (starye istiny i novoe myshlenie) [Philosophy of economics: Old truths and new thinking], Moscow, 1991.

[13] G.M. Buldyk. Formirovanie matematicheskoj kul'tury ekonomista $\mathrm{v}$ vuze [Formation of the mathematical culture of an economist in higher education institution], Ph.D. thesis in pedagogical sciences, Belarusian University Publishing House, Minsk, 1997.

[14] A.V. Dorofeev. Formirovanie nauchnogo myshleniya v processe matematicheskoj podgotovki pedagogov [Formation of scientific thinking in the course of mathematical training of teachers], Bulletin of Higher School, Almamater, Vol.6, 33-34, 2006.

[15] O.A. Okuneva. Predmet matematicheskogo cikla v sisteme professional'noj podgotovki budushchih specialistov [Subject of the mathematical cycle in the system of professional training of future specialists]. Natural Science and Humanism, Vol.2, No.4, 2005.

[16] Y.B. Har. Critical thinking in mathematics. Proceedings of the Higher Order Thinking Skills (H.O.T.S) Conference. Ateneo de Manila University, 2011.

[17] D.W. Katzner. Why mathematics in economics? Journal of Post Keynesian Economics, Vol.25, No.4, 561-574, 2003.

[18] E. Ahdhianto, Marsigit, Haryanto, Y. Nurfauzi. Improving Fifth-Grade Students' Mathematical Problem-Solving and Critical Thinking Skills Using Problem-Based Learning, Universal Journal of Educational Research, Vol.8, No.5, 2012-2021, 2020

[19] J.C. Anito, M.P.E. Morales. The Pedagogical Model of Philippine STEAM Education: Drawing Implications for the Reengineering of Philippine STEAM Learning Ecosystem, Universal Journal of Educational Research, Vol.7, No.12, 2662-2669, 2019. 